\title{
'PENGARUH PENGGUNAAN TERAK dan FLY ASH SEBAGAI BAHAN TAMBAH TERHADAP KUAT TEKAN PAVING BLOCK SEBAGAI SUPLEMEN BAHAN AJAR MATERI MATA KULIAH TEKNOLOGI BETON PTB FKIP UNS"
}

\author{
Rudy Wibisono ${ }^{1}$, Anis Rahmawati ${ }^{2}$, Ida Nugroho Saputro ${ }^{3}$ \\ Pendidikan Teknik Bangunan, Universitas Sebelas Maret \\ e-mail: rudywibie48@gmail.com
}

\begin{abstract}
ABSTRAK: Penelitian mengenai paving block bertujuan untuk mengetahui ketebalan minimum paving block dengan bahan tambah terak dan fly ash jika ditinjau terhadap kuat tekannya berdasarkan SNI 03-0691-1996. Penelitian ini, membuat 7 variasi ketebalan dengan 2 variasi penambahan fly ash yang proporsi campuran pertama $1 \mathrm{pc}: 6 \mathrm{ps}: 3 \mathrm{t}$, fly ash 5\% dengan variasi ketebalan $7 \mathrm{~cm}, 6$ $\mathrm{cm}, 5 \mathrm{~cm}, 4 \mathrm{~cm}, 3 \mathrm{~cm}$ dan $2 \mathrm{~cm}$ serta perbandingan proporsi yang ke dua adalah 1 pc : 6 ps : 3t, fly ash 10\% dengan variasi ketebalan $7 \mathrm{~cm}, 6 \mathrm{~cm}, 5 \mathrm{~cm}, 4 \mathrm{~cm}, 3 \mathrm{~cm}$ dan $2 \mathrm{~cm}$. Pada penelitian ini menggunakan faktor air semen mendekati 0,5. Semen yang digunakan dalam penelitian ini adalah semen portland tipe I dengan benda uji dites dalam umur 28 hari.

Ketebalan minimum paving block terdapat pada ketebalan $5 \mathrm{~cm}$ dengan penggunaan fly ash $10 \%$ yang menghasilkan kuat tekan rata - rata 9,861 $\mathrm{MPa}$ dimana pada ketebalan ini termasuk paving block mutu kelas D dengan tujuan penggunaanya adalah penggunaan pada taman.
\end{abstract}

Kata Kunci : paving block, terak, fly ash, Ketebalan minimum paving block, Bahan Ajar paving block

\begin{abstract}
The research was purposed to find out the minimum thickness of the paving blocks with slag material and fly ash added according to the compressive strength by SNI 03-0691-1996. The research made 7 variations of thickness with 2 variations of fly ash addition. The first paving block mix proportion was $1 \mathrm{pc}$ : $6 \mathrm{ps}: 3 \mathrm{t}$ : fly ash $5 \%$ with variation of the thickness of $7 \mathrm{~cm}$, $6 \mathrm{~cm}, 5 \mathrm{~cm}, 4 \mathrm{~cm}, 3 \mathrm{~cm}$ and $2 \mathrm{~cm}$. The second paving block mix proportion was 1 pc: 6 ps: 3t : 10\% fly ash with thickness variation $7 \mathrm{~cm}, 6 \mathrm{~cm}, 5 \mathrm{~cm}, 4 \mathrm{~cm}, 3 \mathrm{~cm}$ and $2 \mathrm{~cm}$. The paving block was made of Portland Cements Type I with watercement factor approaching 0.5 and tested until the paving block was 28 days old.

The applicable minimum thickness of paving blocks was $5 \mathrm{~cm}$ with $10 \%$ of fly ash which has average compressive strength about 9.861 M.pa. The thickness of paving block $(5 \mathrm{~cm})$ belonging of D-class quality and made to be used for making a park.
\end{abstract}

Keywords : paving block, slag, fly ash, minimum thickness, teaching material

\footnotetext{
${ }^{1}$ Mahasiswa Program Studi Pendidikan Teknik Bangunan FKIP UNS

${ }^{2}$ Pembimbing I Anis Rahmawati, S.T., M.T.

${ }^{3}$ Pembimbing II Ida Nugroho S, S.T., M.Eng.
} 


\section{PENDAHULUAN}

Tingginya

laju

pertumbuhan penduduk berbanding lurus dengan peningkatan pembangunan. Indonesia adalah negara dengan jumlah penduduk mencapai 23.641.326 jiwa menurut sensus penduduk oleh Badan Pusat Statisik pada tahun 2010. Peningkatan pembangunan itu tentu akan berdampak pada kebutuhan material bangunan. Material bangunan harus disediakan dalam jumah yang besar. Akan tetapi, hal ini akan berbanding terbalik dengan ketersediaan bahan bangunan. Salah satu cara untuk mengatasinya adaah memanfakan sumber daya alternatif tertentu yang tersedia dalam jumlah yang besar dengan tujuan meminimalisir penggunaan material bangunan yang semakin berkurang.

Paving block merupakan salah satu elemen bahan bangunan yang dibuat dari campuran semen portland atau sejenisnya, agregat, air dengan atau tambahan lainnya yang tidak mengurangi mutu bata beton tersebut (SNI-03-0691-1996). Paving block mulai dikenal di Indonesia tahun 1977/ 1978.
Kebutuhan paving block semakin bertambah dari waktu ke waktu. Peningkatan kebutuhan paving block ini menjadikan kebutuhan material bahan penyusunnya bertambah.

Bahan penyusun Paving block termasuk ke dalam sumber daya alam yang dapat diperbaharui. Akan tetapi, jangka waku yang dibutuhkan untuk memperbaharui relaif lama. Kontrol terhadap sumber daya ini perlu dilakukan. Pemanfaatan sumber daya alternatif merupakan cara efektif yang dapat dilakukan. Salah satu pemanfaatan sumber daya alternatif ini adalah pemanfaatan limbah atau sampah yang mana pemanfaatannya kurang maksimal. Adapun salah satu limbah yang dapat dimafaatkan dengan baik adalah limbah pengecoran logam. Industri pengecoran yang ada di desa Batur kecamatan Ceper merupakan industri yang bergerak di bidang pengolahan logam. Industri ini menghasilkan sisa material yang berupa terak/ slag yang sangat banyak.

Terak merupakan bongkahan yang berukuran sedang sampai halus menyerupai agregat

${ }^{1}$ Mahasiswa Program Studi Pendidikan Teknik Bangunan FKIP UNS

${ }^{2}$ Pembimbing I Anis Rahmawati, S.T., M.T.

${ }^{3}$ Pembimbing II Ida Nugroho S, S.T., M.Eng. 
kasar. Keberadaan terak ini biasanya oleh industri hanya ditumpuk. Sedangkan pemanfaatan terak oleh masyarakat sekitar hanya sebagai urugan. Hal ini bertentangan dengan Kementrian Lingkungan Hidup yang menyatakan bahwa limbah atau slag baja yang biasanya dihasilkan oleh industri di Indonesia masih berbentuk bongkahan masih termasuk limbah yang berbahaya dan beracun (B3) dan kemungkinan besar keberadannya di dalam tanah akan mempengaruhi tanah di sekitarnya (http://news.ipb.ac.id, 2010).

Ditinjau dari bentuknya terak mempunyai karakteristik yang hampir sama dengan agregat kasar, hanya saja pada permukaannya lebih halus. Kelebihan dari terak baja ini mengandung $40 \%$ silika yang dapat memberikan daya ikat yang kuat antara semen dengan agregat. Berat jenis terak tergolong besar yaitu $2800 \mathrm{~kg} / \mathrm{m}^{3}$.

Dari paparan di atas maka dimungkinkan terak berpotensi dijadikan bahan tambah material bangunan seperti beton, batako, dan paving block. Akan tetapi, berat jenis terak yang begitu besar maka terak akan lebih tepat jika digunakan sebagai bahan tambah pada material bangunan komponen strukur bawah. Paving block merupakan salah satu material bangunan komponen pellapis jalan. Hal ini sejalan dengan hasil penelitian Isah Iriawan (2011) yang menyatakan bahwa penambahan terak akan meningkatkan kuat tekan paving block.

Fly ash merupakan hasil pembakaran batu bara pada tungku pembangkit listrik tenaga uap, yang berbentuk halus, bundar, serta bersifat pozolanik (Fathoni, 2013). Sedangkan pozzolan adalah suatu bahan alam atau buatan yang sebagian besar terdiri dari unsurunsur silika dan atau aluminat yang reaktif (SNI 03-6863-2002). Senyawa silika-alumina aktif yang terkandung dalam fly ash dapat bereaksi dengan kalsium hidroksida pada suhu kamar dan adanya air yang cukup banyak membentuk senyawa stabil yang mempunyai sifat-sifat seperti semen (PT.Semen Andalas, 1998) dengan unsur dominan unsur $\mathrm{CaO}$ sebanyak $15,2 \%$

${ }^{1}$ Mahasiswa Program Studi Pendidikan Teknik Bangunan FKIP UNS

${ }^{2}$ Pembimbing I Anis Rahmawati, S.T., M.T.

${ }^{3}$ Pembimbing II Ida Nugroho S, S.T., M.Eng. 
dan Silika $\left(\mathrm{SiO}_{2}\right)$ sebanyak 31,45\% (Muhardi, dkk, 2007).

Abu terbang sendiri tidak memiliki kemampuan mengikat seperti halnya semen. Tetapi dengan kehadiran air dan ukuran partikelnya yang halus, oksida silika yang dikandung oleh abu terbang akan bereaksi secara kimia dengan kalsium hidroksida yang terbentuk dari proses hidrasi semen dan menghasilkan zat yang memiliki kemampuan mengikat (Roni Ardiansyah,2010). Dengan demikian, beton yang di dalamnya terkandung abu terbang akan memiliki kekuatan yang lebih besar karena ada tambahan kekuatan dari rekasi antara sisa hidrasi semen dengan abu terbang. Penelitian Mardiono (2010) menunjukkan paving block dengan penambahan fly ash $15 \%$ dapat meningkatkan kuat desak dari 20,328 MPa menjadi 29,946 MPa.

Hasil penelitian Isah Iriawan

$$
\text { menunjukkan bahwa }
$$
penambahan terak berpengaruh positif terhadap kenaikan kuat tekan Paving Block, dimana kekuatan tertinggi dicapai pada penambahan terak maksimal yang digunakan dalam penelitian tersebut ( 1 semen: 6 pasir: 2 terak) dengan kuat tekan 18,09 MPa sehingga belum diketahui nilai optimal penambahan terak. Berdasarkan pada kondisi-kondisi tersebut, maka perlu dilakukan penelitian lanjutan untuk mengetahui pengaruh penggunaan terak sebagai bahan tambah pada pembuatan Paving Block. Sebagai hasil dari penelitian ini nanti adalah diharapkan akan diperoleh proporsi campuran bahan penyusun Paving Block dengan bahan tambah terak baja dan abu terbang (fly ash) untuk memperoleh kuat tekan yang paling optimal.

Dari paparan di atas maka dilakukan penelitian ketebalan minimum paving block yang sudah ditambahkan dengan terak ataupun fly ash akan menghasilkan kuat tekan standar sesuai SNI 03-0691-1996 dimana ketebalan standar paving block berdasarkan SNI 03-0691-1996 adalah $6 \mathrm{~cm}$. "Ketebalan minimum paving block dengan bahan tambah terak dan fly ash sesuai kualitas mutu SNI 03-0691-1996 sebagai Suplemen Materi Mata Kuliah Teknologi Beton PTB FKIP UNS”. Dengan ketebalan

${ }^{1}$ Mahasiswa Program Studi Pendidikan Teknik Bangunan FKIP UNS

${ }^{2}$ Pembimbing I Anis Rahmawati, S.T., M.T.

${ }^{3}$ Pembimbing II Ida Nugroho S, S.T., M.Eng. 
minimum paving block yang sudah ditambahkan terak dan fly ash akan menghasikan kuat tekan yang sesuai dengan SNI, sehingga diperoleh pengetahuan baru mengenai bahan bangunan yang dapat meminimalisir kebutuhan bangunan dan juga dapat mengurangi pencemaran lingskungan. Serta ilmu ini dapat membantu dalam mempelajari mata kuliah teknologi beton.

\section{Teknologi Beton}

Teknologi Beton merupakan mata kuliah wajib yang harus diambil oleh mahasiswa Pendidikan Teknik Bangunan (PTB) dengan beban capaian 2 SKS. Mata kuliah ini membahas mengenai macammacam dan karakteristik agregat atau bahan penyusun beton, perkembangan teknologi beton baik itu bahan-bahan campuran beton, inovasi bahan tambah campuran beton, pengujian material beton dan beton jenis lain termasuk materi pokok didalamnya.

\section{Paving Block}

Menurut SNI 03-0691-1996, bata beton (paving block) adalah suatu komposisi bahan bangunan yang dibuat dari campuran semen portland atau bahan perekat hidrolis sejenisnya, air dan agregat dengan atau tanpa bahan tambahan lainnya yang tidak mengurangi mutu bata beton tersebut.

Syarat umum bata beton (paving block) berdasarkan SNI-03061-1996 adalah sebagai berikut :

1) Sifat tampak

Bata beton harus mempunyai permukaan yang rata, tidak terdapat retak-retak dan cacat, bagian sudut dan rusuknya tidak mudah direpihkan dengan kekuatan jari tangan.

2) Ukuran

Bata beton harus mempunyai ukuran tebal nominal minimum 60 mm dengan toleransi $+8 \%$

\section{Bahan Penyusun Paving Block}

Bahan penyusun penyusun dalam peneitian ini adalah semen, agregat (pasir, terak dan fly ash) dan air.

\section{Kuat Tekan}

Kuat tekan paving block adalah besarnya beban per satuan

\footnotetext{
${ }^{1}$ Mahasiswa Program Studi Pendidikan Teknik Bangunan FKIP UNS

${ }^{2}$ Pembimbing I Anis Rahmawati, S.T., M.T.

${ }^{3}$ Pembimbing II Ida Nugroho S, S.T., M.Eng.
} 
luas, yang menyebabkan benda uji paving block hancur bila dibebani dengan gaya tekan tertentu yang dihasilkan oleh mesin tekan ( SNI 03-1974-1990)

Salah satu alat yang digunakan untuk uji kuat tekan adalah Compressing Testing Machine ( CTM ) yang menggunakan prinsip pompa hidrolik.

Berikut ini merupakan persyaratan mutu kuat tekan paving block sesuai SNI 03-0691-1996 :

Tabel 1 Persyaratan Mutu Paving Block SNI-03-0691-1996

\begin{tabular}{cccccc}
\hline Mutu & Kuat Tekan (MPa) & \multicolumn{2}{c}{$\begin{array}{c}\text { Ketahanan Aus } \\
(\mathrm{mm} / \mathrm{menit})\end{array}$} & $\begin{array}{c}\text { Penyerapan } \\
\text { air rata-rata } \\
\text { maks }\end{array}$ \\
& & & & & $\%$ \\
\cline { 2 - 6 } & Rata - rata & Min & Rata - rata & Maks & $\%$ \\
\hline A & 40 & 35 & 0,090 & 0,103 & 3 \\
\hline B & 20 & 17 & 0,130 & 0,149 & 6 \\
\hline C & 15 & 12,5 & 0,160 & 0,184 & 8 \\
\hline
\end{tabular}

\section{METODE PENELITIAN}

Penelitian ini dilaksanakan di beberapa tempat, yaitu :

a. Pengujian bahan, pengujian kuat tekan dilaksanakan di Laboratorium PTB JPTK FKIP Universitas Sebelas Maret b. Pembuatan Paving Block dilaksanakan di Pabrik Paving dan Genteng Restu Adi

Penelitian ini menggunakan metode kuantitatif dengan pendekatan eksperimen yang dilaksanakan di laboratorium dengan kondisi dan perlengkapan yang disesuaikan dengan kebutuhan untuk mendapatkan data tentang ketebalan minimum paving block dengan bahan tambah terak dan fly ash sesuai kualitas mutu SNI 03-06911996 sebagai suplemen materi mata kuliah Teknologi Beton PTB FKIP UNS.

Dalam penelitian ini benda uji dibuat dengan menambah sebagian agregat halus dengan terak dalam pembuatan paving block. Setelah itu benda uji bisa dilakukan pengujian setelah umur 28 hari, karena pada umur tersebut memiliki puncak kekuatan dan setelah umur 28 hari peningkatan kekuatannya sangat sedikit. Adapun alur penelitian dan tahapannya sebagai berikut:

${ }^{1}$ Mahasiswa Program Studi Pendidikan Teknik Bangunan FKIP UNS

${ }^{2}$ Pembimbing I Anis Rahmawati, S.T., M.T.

${ }^{3}$ Pembimbing II Ida Nugroho S, S.T., M.Eng. 


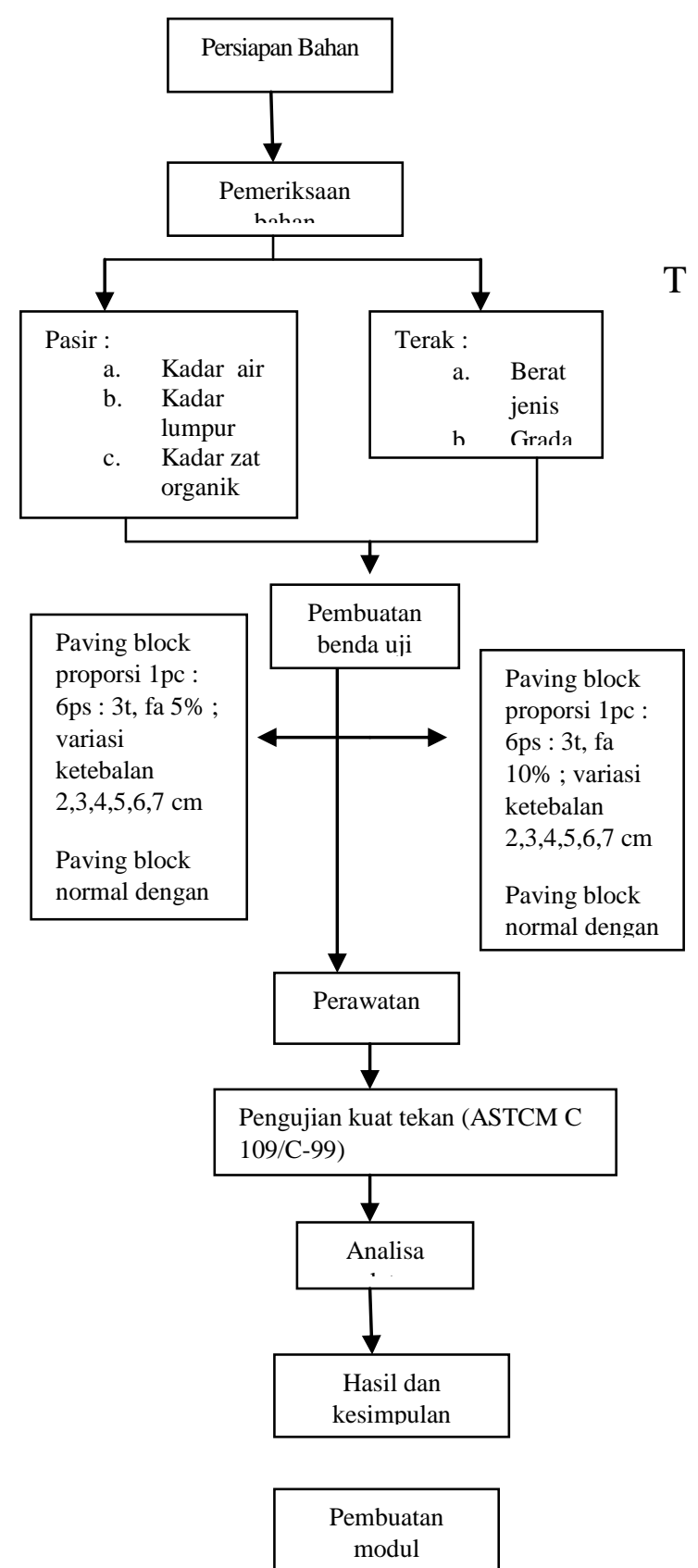

Gambar 1. Diagram Alur

Peneletian

Sampel dalam penelitian ini adalah 36 buah benda uji. Penelitian ini menggunakan semua anggota populasi untuk dijadikan sampel.
Berikut rincian sampel pada tabel Tabel 2

T Tabel 2 Rincian Benda Uji

\begin{tabular}{|c|c|c|c|c|c|c|c|c|}
\hline \multirow{2}{*}{ Pengujian } & \multirow{2}{*}{$\begin{array}{l}\text { Proporsi } \\
\text { campuran }\end{array}$} & \multicolumn{6}{|c|}{ Variasi ketebalan } & \multirow{2}{*}{$\begin{array}{l}\text { Jumlah } \\
\text { Sampel }\end{array}$} \\
\hline & & 7 & 6 & 5 & 4 & 3 & 2 & \\
\hline \multirow{5}{*}{$\begin{array}{c}\text { Kuat } \\
\text { Tekan }\end{array}$} & $1 \mathrm{pc}: 6 \mathrm{ps}: 3 \mathrm{t}$ & & & & & & & \\
\hline & & 6 & 6 & 6 & 6 & 6 & 6 & 36 \\
\hline & $5 \%$ fly ash & & & & & & & \\
\hline & $\begin{array}{c}1 \mathrm{pc}: 6 \mathrm{ps}: 3 \mathrm{t}, \\
10 \% \text { fly ash }\end{array}$ & 6 & 6 & 6 & 6 & 6 & 6 & 36 \\
\hline & $1 \mathrm{pc}: 6 \mathrm{ps}$ & - & 6 & - & - & - & - & 6 \\
\hline \multicolumn{8}{|c|}{ Jumlah Sampel } & 78 \\
\hline \multicolumn{2}{|c|}{ Sumber } & & & \multicolumn{4}{|c|}{ dalam } & \\
\hline \multicolumn{2}{|c|}{ pelaksanaan } & liti & & \multicolumn{4}{|c|}{ ini } & \\
\hline \multicolumn{2}{|c|}{ dikelompokkan } & ni & adi & & $\mathrm{d}$ & & & \\
\hline
\end{tabular}

a) Data primer merupakan data yang diperoleh dari hasil eksperimen dan pengamatan di laboratorium, yang berupa hasil uji bahan dan kuat tekan terhadap paving block umur 28 hari.

b) Data sekunder merupakan data yang diperoleh dari referensi informasi penunjang yang berkaitan dengan penelitian yang dilaksanakan, yang berupa buku-buku penunjang maupun hasil penelitian yang

${ }^{1}$ Mahasiswa Program Studi Pendidikan Teknik Bangunan FKIP UNS

${ }^{2}$ Pembimbing I Anis Rahmawati, S.T., M.T.

${ }^{3}$ Pembimbing II Ida Nugroho S, S.T., M.Eng. 
terdahulu atau yang relevan dengan penelitian yang dilaksanakan.

Analisis data yang digunakan untuk mengetahui ketebalan minimum paving block yang sesuai mutu SNI 03-0691-1996 yaitu dengan deskriptif kuantitatif. Dalam melakukan deskriptif kuantitatif peneliti akan membandingkan kuat tekan paving block yang ditambah terak yang dan fly ash yang ketebalannya bervariasi dengan kuat tekan paving block normal dan persyaratan mutu kuat tekan paving block sesuai SNI. Pada hasil kuat tekan paving block dilakukan analisis yaitu menggunakan standar deviasi . hal ini dilakukan mengingat adanya faktor kesalahan pada pengujian paving block. Dari hasil analisis tersebut akan didapat perubahan kuat tekan paving block terak dan fly ash dengan kuat tekan paving block normal dan ketebalan minimum paving block yang sesuai mutu SNI 03-0691-1996.

\section{HASIL DAN PEMBAHASAN}

Hasil Pengujian kuat tekan optimum Paving Block dengan penambahan terak dan fly ash dapat dilihat pada tabel 3, 4 dan 5 berikut.

Tabel 3 Kuat Tekan Paving Block Dengan Fly Ash 5\%

\begin{tabular}{|c|c|c|c|c|c|c|}
\hline \multirow{2}{*}{$\begin{array}{c}\text { Tebal } \\
(\mathrm{cm})\end{array}$} & \multicolumn{5}{|c|}{ Kuat Tekan (MPa) } & \begin{tabular}{c} 
Kuat \\
Tekan \\
Rerata \\
nyyyyyn \\
\cline { 2 - 8 }
\end{tabular} \\
\hline 7 & 13,194 & 12,847 & 12,847 & 13,889 & - & 13,194 \\
\hline 6 & 10,764 & 11,458 & 9,722 & 11,458 & - & 10,851 \\
\hline 5 & 8,333 & 7,986 & 7,986 & 8,681 & - & 8,247 \\
\hline 4 & 6,944 & 6,944 & 6,944 & 10,069 & 5,903 & 7,726 \\
\hline
\end{tabular}

Tabel 4.Kuat Tekan Paving Block Dengan Fly Ash 10\%

\begin{tabular}{|c|c|c|c|c|c|c|}
\hline \multirow{2}{*}{$\begin{array}{c}\text { Tebal } \\
(\mathrm{cm})\end{array}$} & \multicolumn{5}{|c|}{ Kuat Tekan (MPa) } & $\begin{array}{c}\text { Kuat } \\
\text { Tekan } \\
\text { Rerata } \\
\end{array}$ \\
\cline { 2 - 7 } & 1 & 2 & 3 & 4 & 5 & MPa) \\
\hline 7 & 17,014 & 18,056 & 18,403 & 11,111 & - & 16,146 \\
\hline 6 & 11,111 & 11,111 & 12,500 & - & - & 11,574 \\
\hline 5 & 9,722 & 8,333 & 10,069 & 10,069 & 11,111 & 9,861 \\
\hline 4 & 7,292 & 8,333 & 8,333 & 7,986 & 7,986 & 7,986 \\
\hline
\end{tabular}

Tabel 5 Kuat Tekan Paving Block normal

\begin{tabular}{|c|c|c|c|c|c|c|}
\hline \multirow{2}{*}{$\begin{array}{c}\text { Tebal } \\
(\mathrm{cm})\end{array}$} & \multicolumn{5}{|c|}{ Kuat Tekan (MPa) } & \begin{tabular}{c} 
Kuat \\
Tekan \\
Rerata \\
\cline { 2 - 7 }
\end{tabular} \\
\cline { 2 - 7 } \\
\hline 6 & 1 & 2 & 3 & 4 & 5 & MPa) \\
\hline
\end{tabular}

\section{Kuat Tekan Paving Block}

Hipotesis pertama yang menyatakan bahwa ada perubahan kuat tekan paving block dengan bahan tambah terak dan fly ash terhadap kuat tekan paving block normal dengan tebal $6 \mathrm{~cm}$. Pengujian

\footnotetext{
${ }^{1}$ Mahasiswa Program Studi Pendidikan Teknik Bangunan FKIP UNS

${ }^{2}$ Pembimbing I Anis Rahmawati, S.T., M.T.

${ }^{3}$ Pembimbing II Ida Nugroho S, S.T., M.Eng.
} 
hipotesis ini menggunakan Microsoft excel dengan menggunakan metode deskriptif kuantitatif, yakni dengan cara menggambarkan perubahan kuat tekan paving block dengan bahan tambah terak dan fly ash dengan paving block normal dimana perubahan kuat tekan yang dimaksud adalah perubahan kuat tekan rata rata seperti pada tabel 6 yang kemudian akan ditampilkan dengan grafik perubahan kuat tekan pada gambar 2

Tabel 6 Kuat Tekan Rata - Rata

\begin{tabular}{|l|c|c|c|c|}
\hline \multirow{2}{*}{$\begin{array}{l}\text { Jenis Paving } \\
\text { Block }\end{array}$} & \multicolumn{4}{|c|}{ Kuat Tekan Rata -Rata (MPa) } \\
\cline { 2 - 5 } & $7 \mathrm{~cm}$ & $6 \mathrm{~cm}$ & $5 \mathrm{~cm}$ & $4 \mathrm{~cm}$ \\
\hline $\begin{array}{l}\text { paving block } \\
\text { normal }\end{array}$ & - & 10,24 & - & - \\
\hline $\begin{array}{l}\text { paving block } \\
\text { terak dan fly ash } \\
5 \%\end{array}$ & 13,194 & 10,851 & 8,247 & 7,726 \\
\hline $\begin{array}{l}\text { paving block } \\
\text { terak dan fly ash } \\
10 \%\end{array}$ & 16,146 & 11,574 & 9,861 & 7,986 \\
\hline
\end{tabular}

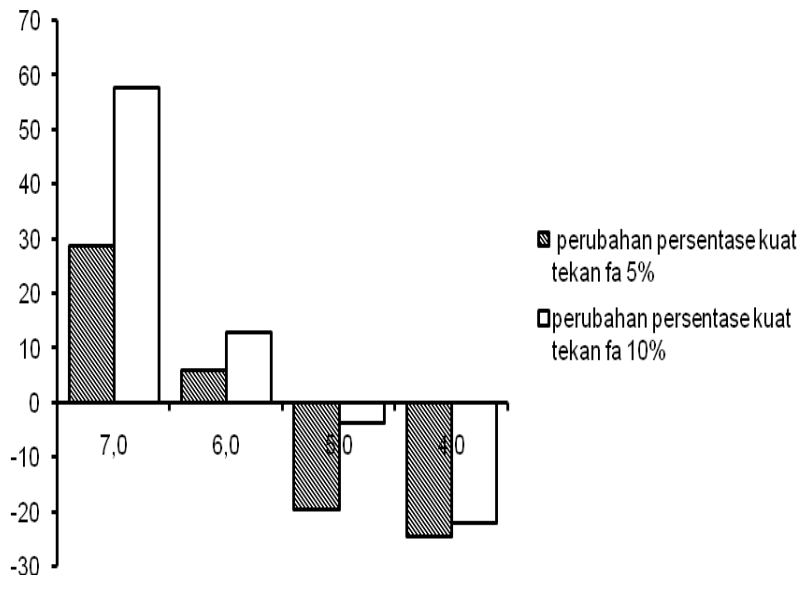

Gambar 2 Persentase Perubahan Kuat Tekan Paving Block Dengan Bahan Tambah Terak Dan Fly Ash Terhadap Kuat Tekan Paving block normal

\section{Ketebalan minimum Paving Block}

Hipotesis kedua menyatakan bahwa ada ketebalan minimum paving block yang menghasilkan kuat tekan standar sesuai SNI 030691-1996 pada umur 28 hari. Untuk membuktikan hipotesis tersebut akan diuji dengan perhitungan kuat tekan paving block pada masing - masing variasi, dapat dilihat pada gambar $\mathbf{3}$

${ }^{1}$ Mahasiswa Program Studi Pendidikan Teknik Bangunan FKIP UNS

${ }^{2}$ Pembimbing I Anis Rahmawati, S.T., M.T.

${ }^{3}$ Pembimbing II Ida Nugroho S, S.T., M.Eng. 


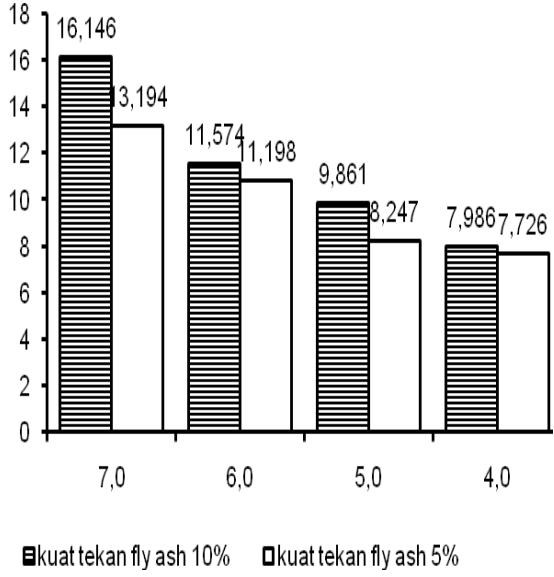

Gambar 3 Grafik Perbandingan Kuat Tekan Paving Block Ditambah Terak dan Fly Ash Dengan Berbagai Ketebalan Terhadap SNI 03-06911996

\section{SIMPULAN}

Berdasarkan hasil analisis data dan pembahasan dapat diambil kesimpulan sebagai berikut:

1. Ada perubahan kuat tekan paving block dengan penambahan terak dan fly ash dengan berbagai ketebalan terhadap kuat tekan paving block normal dengan tebal $6 \mathrm{~cm}$. Perubahan yang terjadi tergantung pada tebal paving block. Perubahan positif (peningkatan kuat tekan) terjadi pada paving block dengan tebal 6 $\mathrm{cm}$ dan $7 \mathrm{~cm}$ baik pada penambahan fly ash 5\% dan $10 \%$

2. Peningkatan pada tebal $6 \mathrm{~cm}$ dengan penambahan fly ash 5\% sebesar 5,964\% dan untuk tebal 6 $\mathrm{cm}$ dengan penambahan fly ash $10 \%$ sebesar $13,028 \%$, sedangkan peningkatan pada ketebalan $7 \mathrm{~cm}$ dengan penambahan fly ash 5\% adalah $28,852 \%$ dan untuk tebal $7 \mathrm{~cm}$ dengan penambahan fly ash $10 \%$ mengalami peningkatan kuat tekan sebesar 57,674\%.

3. Penurunan pada tebal $5 \mathrm{~cm}$ dengan penambahan fly ash $10 \%$ sebesar $3,7 \%$ dan untuk tebal 5 cm dengan penambahan fly ash $5 \%$ sebesar $19,468 \%$, sedangkan untuk ketebalan $4 \mathrm{~cm}$ dengan penambahan fly ash 5\% adalah $24,453 \%$ dan untuk tebal $4 \mathrm{~cm}$ dengan penambahan fly ash $10 \%$ mengalami penurunan kuat tekan sebesar $22,01 \%$.

4. Pada penelitian ini didapatkan ketebalan minimum paving block yang ditambah terak dan fly ash yaitu pada ketebalan $5 \mathrm{~cm}$ dengan penambahan fly ash $10 \%$ yang menghasilkan kuat tekan sebesar 9,861 MPa dengan kelas paving D.

${ }^{1}$ Mahasiswa Program Studi Pendidikan Teknik Bangunan FKIP UNS

${ }^{2}$ Pembimbing I Anis Rahmawati, S.T., M.T.

${ }^{3}$ Pembimbing II Ida Nugroho S, S.T., M.Eng. 


\section{DAFTAR PUSTAKA}

Anggodo, Ari. (2014). Pengaruh Penggunaan Abu Batu Bara (Fly Ash) Terhadap Kuat Tekan Paving Block. Skripsi. Fakultas Teknik. Universitas 17 Agustus 1945. Samarinda

Anonim. SK SNI S 04-1989-F. Persyaratan Bahan Bangunan.

Anonim. 1996. Batu Beton (Paving Block) (SK SNI-03-0691-1996). Yayasan

Asroni, Ali. (2010) Balok dan pelat beton bertulang. Graha Ilmu. Yogyakarta

Cornellia Rimba, dkk. (2009). Konstruksi Bangunan I-TA251. Bandung: Jurusan Pendidikan Teknik Arsitektur, FPTK Universitas Pendidikan Indonesia.

Dewangga,, I.G. (2012). Pengaruh Fly Ash Terhadap Paving Block Dengan Metode Pressing Hidrolik Sebagai Proses Pembuatannya. Jurnal Skripsi. Jurusan Teknik Sipil. Fakultas Teknik. Universitas Jember. Jember

Dewi, triana. 2013. Pengaruh Penggunaan Terak Sebagai Pengganti Agregat Kasar Terhadap Kuat Lentur Dan Berat Jenis Pada Beton Normal

Dengan Perbandingan 1:2:3. Skripsi. FKIP. UNS. Surakarta
Iriawan, Isah. (2012). Pengaruh penambahan terak terhadap kuat tekan paving block. Skripsi. FKIP. UNS. Surakarta

Lembaga Penyelidikan Masalah Bangunan: Jakarta

Mardiono. 2010. Pengaruh Pemanfaatan Abu Terbang ( Fly Ash) Dalam Beton Mutu Tinggi. Skripsi. Jurusan Teknik Sipil. Fakultas Teknik Sipil dan Perencanaan. Universitas Gunadarma. Jakarta Pusat

Ngarifin. 2015. Pengaruh Penambahan Fly Ash Terhadap Kuat Tekan, Berat Jenis, Dan Daya Hambat Panas Bata Beton Ringan Foam Sebagai Suplemen Bahan Ajar Mata Kuliah Teknologi Beton Pada Semester III PTB FKIP UNS. Skripsi. FKIP. UNS. Surakarta

Nugraha, Paul dan Antoni. (2003). Teknologi Beton. Yogyakarta

Safitri, Endah dan Djumari (2009). Kajian Teknis dan Ekonomis Pemanfaatan Limbah Batu Bara (Fly Ash) Pada Produksi Paving Block Paving Block. Jurnal Teknik Sipil. Fakultas Teknik. Universitas Sebelas Maret. Surakarta

Winarsunu, Tulus. (2007). Statistik Dalam Penelitian Psikologi Dan Pendidikan . Universitas Muhammadiyah Malang. Malang.

${ }^{1}$ Mahasiswa Program Studi Pendidikan Teknik Bangunan FKIP UNS

${ }^{2}$ Pembimbing I Anis Rahmawati, S.T., M.T.

${ }^{3}$ Pembimbing II Ida Nugroho S, S.T., M.Eng. 
${ }^{1}$ Mahasiswa Program Studi Pendidikan Teknik Bangunan FKIP UNS

${ }^{2}$ Pembimbing I Anis Rahmawati, S.T., M.T.

${ }^{3}$ Pembimbing II Ida Nugroho S, S.T., M.Eng. 